Sains Malaysiana 47(5)(2018): 923-929

http://dx.doi.org/10.17576/jsm-2018-4705-07

\title{
Experimental and DFT Investigation on the Influence of Electron Donour/Acceptor on the Hydrogen Bonding Interactions of 1-(1,3-Benzothiazol-2- y1)-3-(R-benzoylthiourea)
}

(Uji Kaji dan Penyiasatan DFT mengenai Pengaruh Penderma/Penerima Elektron pada Interaksi Ikatan Hidrogen dalam 1- (1,3-Benzotiazol-2-yl) -3- (R-benzoylthiourea))

\author{
MUHD HAFIZI B. ZAINAL, WUN FUI MARK-LEE, SYAHIDAH MOHD TAHIR, \\ ISHAK B. AHMAD \& MOHAMMAD B. KASSIM*
}

\begin{abstract}
The presence of two different chromophores in benzothiazole molecule namely benzothiazole and aromatic rings lead to interesting chemical and biological properties that attract more researches on the compounds. Three new benzothiazolylbenzoythiourea compounds namely 1-(1,3-benzothiazol-2-yl)-3-(benzoylthiourea) (BBT), 1-(1,3-benzothiazol-2-yl)-3(4-chlorobenzoylthiourea) (BBT-4Cl) and 1-(1,3-benzothiazol-2-yl)-3-(4-methoxybenzoylthiourea) (BBT-4OCH ${ }_{3}$ with different electron withdrawing substituents $(R)$ at the para positions on the benzene ring of benzoylthiourea ring have been synthesized from the reaction of $\mathrm{R}$-benzoyl isothiocyanate $\left(\mathrm{R}=\mathrm{H}, \mathrm{Cl}\right.$, and $\left.\mathrm{OCH}_{3}\right)$ and 2-aminobenzothiazole. The compounds were characterized by spectroscopic techniques (infrared, ${ }^{1} \mathrm{H}$ proton NMR and UV-Vis). The IR spectra showed the frequency signals of $v(C=O), v(C=S), v(N-H)$ at 1664-1673, 1238-1249 and 3031-3055 $\mathrm{cm}^{-1}$, respectively. The ${ }^{1} \mathrm{H}$ proton NMR spectra showed the presence of $N$-H amine and amide signals in the region of (12.14-12.35) and (14.17-14.43) ppm, respectively. The proton signals of the two benzothiazole and benzoylthiourea moieties appear at 7.08-8.16 ppm. A theoretical study based on Density Functional Theory (DFT) and Time-Dependent (TD) DFT was conducted to optimize the geometrical structure and investigate the electronic properties of title compounds. The highest occupied molecular orbital (HOMO) was found on the benzothiazole moiety; while, the lowest-unoccupied molecular orbital (LUMO) was located at the benzoylthiourea fragment. The DFT optimized structures possessed an intramolecular hydrogen bonding and the types of para substituents used influenced the properties of hydrogen bonding.
\end{abstract}

Keywords: Benzothiazolyl-benzoylthiourea; DFT; electron donating groups; electron withdrawing groups; hydrogen bonding interactions

ABSTRAK

Kehadiran dua kromofor yang berbeza di dalam molekul benzotiazol iaitu benzotiazol dan gelang aromatik menyebabkan molekul ini mempunyai ciri kimia dan biologi yang menarik minat para penyelidik terhadap sebatian tersebut. Tiga sebatian benzotiazolil-benzoiltiourea yang baru dengan kumpulan pengganti daripada kumpulan penderma dan kumpulan penerima elektron $(R)$ pada kedudukan para pada gelang benzoiltiourea iaitu 1-(1,3-benzotiazol-2-il)-3(benzoiltiourea) (BBT), 1-(1,3-benzotiazol-2-il)-3-(4-klorobenzoiltiourea) (BBT-4Cl) dan 1-(1,3-benzotiazol-2-il)-3-(4metoksibenzoiltiourea) (BBT-4OCH $\left.\mathrm{H}_{3}\right)$ berjaya disintesis daripada tindak balas $\mathrm{R}$ - benzoil isotiosianat $(\mathrm{R}=\mathrm{H}, \mathrm{Cl}$ dan $\mathrm{OCH}_{3}$ ) dan 2-aminobenzotiazol. Sebatian tersebut telah diciri dengan teknik spektroskopi (inframerah, ${ }^{1} \mathrm{H}$ proton $\mathrm{RMN}$ dan UV-Vis). Spektra inframerah sebatian menunjukkan frekuensi bagi jalur $v(C=O), v(C=S), v(N$ - $H)$ masing-masing

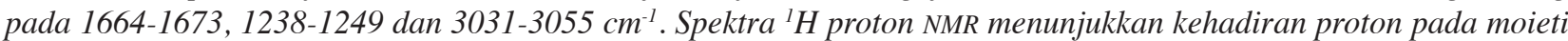
$\mathrm{N}$-H amina dan amida masing-masing pada 12.14-12.35 and 14.17-14.43 ppm. Kehadiran dua moieti benzotiazol dan benzoiltiourea ditunjukkan oleh isyarat proton pada julat 7.08-8.16 ppm. Kajian teori berdasarkan pengiraan dengan kaedah teori fungsi ketumpatan (DFT) dan DFT bersandar masa (TD) telah dijalankan untuk mengoptimumkan struktur geometri dan mengkaji sifat elektronik sebatian tersebut. orbital molekul terisi dengan tenaga tertinggi (HOMO) didapati pada moieti benzotiazol; manakala orbital molekul tidak terisi dengan tenaga terendah (LUMO) didapati pada moieti benzoiltiourea. Ikatan intramolekul hidrogen dapat dioptimumkan melalui DFT dan jenis kumpulan pengganti yang digunakan mempengaruhi sifat ikatan hidrogen tersebut.

Kata kunci: Benzotiazolil-benzoiltiourea; DFT; ikatan hidrogen; kumpulan penarik elektron; kumpulan penderma elektron

\section{INTRODUCTION}

Thiourea compounds are unique and have interesting properties that lead to the development of various applications such as non-linear optical materials that makes thioureas as a potential compound especially for a laser material (Weiqun et al. 2003). The principal 
role of panchromatic dyes is to harvest light spectrum particularly the visible and near-infrared (Li et al. 2013). In addition, thioureas were found to be widely used in several applications such as in the development of electronic and optoelectronic devices (Yusof et al. 2010; Yutronic et al. 2000). Another interesting aspect of thioureas is this compound can act as chelating agents (Alkherraz et al. 2014; Das 1984; Shome et al. 1980) for various metal ions with electronic spectrum extended to the visible region (Mishra et al. 2009), hence, can be utilized as a molecular dye. Meanwhile, compounds based on benzothiazole derivative are known to be employed as organic dyes is photoelectrochemical (Sayama et al. 2002). The study has also shown that benzothiazole derivatives exhibited interesting photochemical properties due to the presence of two different chromophores in the molecule namely benzothiazole and aromatic moiety (Đaković et al. 2009).

Metal complexes of thiourea compounds have shown interesting biological activities such as anti-cancer, antimicrobe, anti-bacterial, anti-fungus, anti-malaria and anti-tuberculosis (Yang et al. 2012). Besides, thiourea compounds have also been used as building blocks in the synthesis of heterocyclic compounds and was claimed to be an important organic compound which acts as corrosion inhibitors and antioxidant (Alkherraz et al. 2014; Katritzky \& Gordeev 1991). Benzoylthiourea and its derivatives are another class of thiourea compounds that have attracted tremendous research activities on their coordination chemistry, analytical and environmental application as well as their biological properties. Benzothiazole and its derivatives are also known to have biological activities such as anti-tumour, anti-bacterial, anti-fungus, anti-inflammatory and anti-allergy (Gao et al. 2007). In addition, rhenium complexes with benzothiazole derivatives were reported to have interesting biological activities and have been studied for application in technetium radiopharmaceuticals for radiotherapy and diagnostic imaging (Schoultz et al. 2016).

The previous study has shown that 1-(benzothiazol2-ylidine)-3-methylthiourea, that contained a tertiary amide, behaves as a bidentate ligand through $S, N$ coordination mode (Sathdeo et al. 2016). Benzoylthiourea contains $N, O$ and $S$ donor atoms that make coordination chemistry of this molecule more interesting as it can behave as a monodentate, bidentate or tridentate ligand (Kurt et al. 2009). The presence of intramolecular and intermolecular hydrogen bonding interactions that influence their coordination chemistry with the main group and transition metal elements (Domìnguez et al. 2002). The $N$-carbamothioylbenzamide moiety in benzoylthiourea molecules plays an important role in determining their coordination modes that saw a ligand with secondary $N$-carbamothioylbenzamide moiety to favour a monodentate $S$ coordination mode due to the presence of an intramolecular hydrogen bonding between the $\mathrm{H}$-amide and the $\mathrm{O}$-carbonyl group to form a 6-membered ring (NHOCNC) (Selvarakumaran et al. 2009; Thompson et al. 1980). On the other hand, benzoylthiourea with a tertiary $N$-carbamothioylbenzamide fragment tends to coordinate in a bidentate manner through os donor atoms since the formation of intramolecular hydrogen bonding was eliminated from the structural feature (Mohammad Halim et al. 2012).

In this study, we report the synthesis of benzothiazolebenzoylthiourea molecules with chloro and methoxy substituent at the para position on the benzene ring of the benzoyl moiety. Chloro and methoxy have been chosen as the substituents since both are electron withdrawing and donating group, respectively, that may influence the formation of the intramolecular hydrogen bonding interactions. The findings from this work can facilitate a better understanding of the structural and intramolecular hydrogen bonding behaviour of these molecules.

\section{EXPERIMENTAL DETAILS}

SYNTHESIS OF 1-(1,3-BENZOTHIAZOL-2-YL)-3-( $R$-BENZOYL) THIOUREA $\left(R=\mathrm{H}, \mathrm{CL}\right.$ AND $\left.\mathrm{OCH}_{3}\right)$

All the compounds were synthesized according to the previous literature methods (Al-abbasi et al. 2011; Perez et al. 2011; Raj et al. 1999; Tan et al. 2014) with some modification. The solution of $R$-benzoyl chloride $(0.01$ $\mathrm{mol})$ in acetone $(25 \mathrm{~mL})$ was added drop-wise to a solution of potassium thiocyanate, $\mathrm{KSCN}(0.01 \mathrm{~mol})$ in acetone $(25$ $\mathrm{mL}$ ). The mixture was stirred for $30 \mathrm{~min}$ and the byproduct, potassium chloride, was removed by filtration to give $R$-benzoyl isothiocyanate as an intermediate product. Then, 2-aminobenzothiazole $(0.01 \mathrm{~mol})$ in acetone $(25 \mathrm{~mL})$ was added to the $R$-benzoyl isothiocyanate solution and left stirring for $2 \mathrm{~h} 30 \mathrm{~min}$ (Figure 1). Lastly, the product was precipitated by addition of $500 \mathrm{~mL}$ cold water and the mixture was left in an ice bath for $2 \mathrm{~h}$. The precipitate was washed with a small volume of cold ethanol to give the desired product.

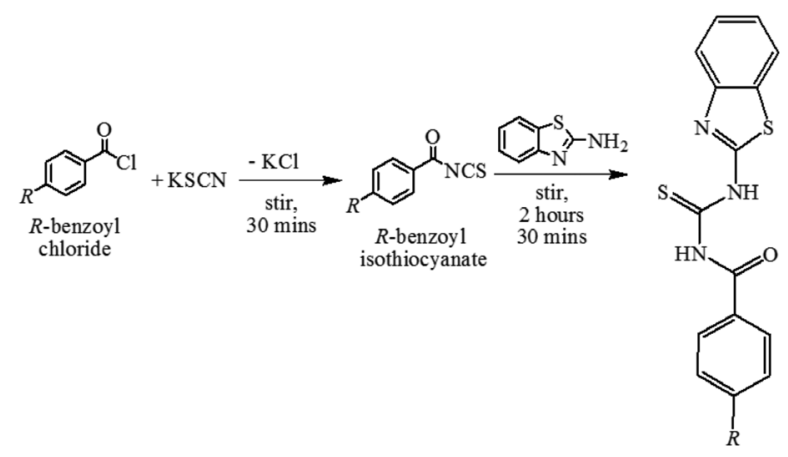

FIGURE 1 . The a two-stage chemical reactions for the synthesis of the 1-(1,3-benzothiazol-2-yl)-3-( $R$-benzoyl)thiourea $(R=\mathrm{H}$, $\mathrm{Cl}$ and $\mathrm{OCH}_{3}$ ) molecules

\section{INSTRUMENTATION}

The IR spectra were obtained using ATR-FTIR Cary 630 FTIR spectrophotometer from Agilent Technologies. The 
${ }^{1} \mathrm{H}$ NMR spectra were recorded by Bruker AVANCE 400 III $\mathrm{HD}$. The analysis on UV-Vis absorption was conducted with AvaSpec-2048L (AVANTES).

\section{COMPUTATIONAL METHODS}

The structural geometry of the molecule was optimised with density functional theory (DFT) and their electronic and absorption properties were calculated with timedependent (TD) DFT. The hybrid function of Lee-Yang-Parr (B3LYP) exchange-correlation functional and 6-311++G $(\mathrm{d}, \mathrm{p})$ basis-set with polarization and diffuse function was used in combination for the calculation (Becke 1993, 1988; Davidson \& Feller 1986; Hehre et al. 1986; Lee et al. 1988). The vibrational frequencies were verified to ascertain that the optimized structure represents local minima. Acetonitrile $(\varepsilon=35.688)$ was considered for the geometry optimization with Tomasi's polarizable continuum model (PCM) (Cossi et al. 2003; Miertuš et al. 1981). It is known that calculations based on the hybrid function (B3LYP) tend to over-estimate the optical energies compared to experimentally obtained results (Fui et al. 2016; MarkLee et al. 2017).

\section{RESULTS AND DISCUSSION}

All the three compounds, BBT, BBT- $4 \mathrm{Cl}$, and BBT- $4 \mathrm{OCH}_{3}$ were synthesized via a condensation reaction with benzoyl isothiocyanate and 2-aminobenzothiazole. The IR spectra of all molecules showed a band at 3303-3304 cm-1 , which is more intense than a normal $\mathrm{N}-\mathrm{H}$ signal from amine group. This observation is attributed to the formation of hydrogen bonding between the $\mathrm{N}-\mathrm{H} \cdots \mathrm{O}$. Thus, the band was assigned as the $v(\mathrm{~N}-\mathrm{H})$ signal for the amide group. The strong stretching vibration signal ascribed to be $v(\mathrm{C}=\mathrm{O})$ was recorded at $1664-1673 \mathrm{~cm}^{-1}$ and the $v(\mathrm{C}=\mathrm{S})$ signal from the thiocyanide group was observed at $1238-1249 \mathrm{~cm}^{-1}$ with a medium-weak intensity. In addition, stretching vibration for $\mathrm{C}=\mathrm{N}$ from the benzoyl ring can be found at 1510-1525 $\mathrm{cm}^{-1}$ and the band at $2912-3003 \mathrm{~cm}^{-1}$ indicates the presence of $\mathrm{C}-\mathrm{H}$ from the benzoyl ring. The stretching frequencies of $\mathrm{C}=\mathrm{O}$ were relatively lower than a free $\mathrm{C}=\mathrm{O}(<1730$ $\mathrm{cm}^{-1}$ ) due to the formation of hydrogen bond (Saeed et al. 2010; Yusof et al. 2010). The functional groups and their vibration frequencies for BBT, BBT- $4 \mathrm{Cl}$, and $\mathrm{BBT}-4 \mathrm{OCH}_{3}$ are collected in Table 1 .

TABLE 1. Vibrational frequencies for BBT, BBT-4Cl and $\mathrm{BBT}-4 \mathrm{OCH}_{3}$ ligands

\begin{tabular}{lccc}
\hline \multirow{2}{*}{$\begin{array}{c}\text { Functional } \\
\text { group }\end{array}$} & \multicolumn{3}{c}{ Frequency $\left(\mathrm{cm}^{-1}\right)$} \\
\cline { 2 - 4 } & BBT & BBT-4Cl & BBT-4OCH $_{3}$ \\
\hline $\mathrm{C}=\mathrm{O}$ & 1672 & 1664 & 1673 \\
$\mathrm{~N}-\mathrm{H}$ (amide) & 3052 & 3031 & 3055 \\
$\mathrm{~N}-\mathrm{H}$ (amine) & 3327 & 3303 & 3304 \\
$\mathrm{C}=\mathrm{S}$ & 1238 & 1239 & 1249 \\
$\mathrm{C}=\mathrm{N}$ & 1510 & 1519 & 1525 \\
\hline
\end{tabular}

The optimized structures of these compounds led to the lowest energy molecular structure with the presence of an intramolecular hydrogen bond. The optimized structure of BBT is shown in Figure 2. The geometrical parameters of selected bond lengths $(\AA)$ and angles $\left(^{\circ}\right)$ of the optimised BBT, BBT-4Cl and BBT- $4 \mathrm{OCH}_{3}$ structures are listed in Table 2 . The structures of the compounds are almost planar due to the intramolecular hydrogen bonding interaction. In Figure 2, the intramolecular hydrogen bonding interaction is expected to occur in the $\mathrm{N} 2-\mathrm{H} 7 \cdots \mathrm{O} 1$ moiety. Table 2 shows the selected geometrical data of DFT for BBT, BBT- $4 \mathrm{Cl}$, and BBT- $4 \mathrm{OCH}_{3}$. The data shows that the length of hydrogen bonding for $\mathrm{BBT}-4 \mathrm{Cl}$ is longer than that of BBT- $4 \mathrm{OCH}_{3}$ because of the electron donating $\mathrm{OCH}_{3}$ group which induced a better electron delocalization through resonance involving the two lone pairs of electrons on the oxygen $\left(\mathrm{OCH}_{3}\right)$ and hence, the $\mathrm{C}=\mathrm{O}$ bond becomes slightly elongated compared to that of BBT $(\Delta=0.002$ $\AA)$. Subsequently, the intramolecular hydrogen bonding involving $\mathrm{O} 1$ atom $(\mathrm{C}=\mathrm{O})$ with $\mathrm{H} 7$ became stronger $(\mathrm{O} 1 \cdots$ H7; shorter by $0.011 \AA$ ) and form a pseudo six-membered ring as shown in Figure 2. The intramolecular hydrogen

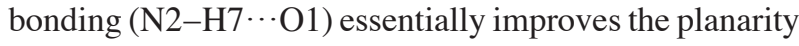
of the two moieties (benzothiazole and benzoylthiourea).



FIGURE 2. The optimised molecular structure of BBT in vacuo showing the intramolecular H-bond (dotted line); B3LYP/6$311++\mathrm{G}(\mathrm{d}, \mathrm{p})$

TABLE 2. Selected geometrical data of DFT optimised (in vacuo) BBT, BBT-4Cl and BBT-4OCH

\begin{tabular}{|c|c|c|c|}
\hline & BBT & BBT-4Cl & $\mathrm{BBT}-4 \mathrm{OCH}_{3}$ \\
\hline \multicolumn{4}{|c|}{ Bond ( } \\
\hline S1-C8 & 1.665 & 1.665 & 1.667 \\
\hline $\mathrm{O} 1-\mathrm{C} 7$ & 1.225 & 1.225 & 1.227 \\
\hline N1-C7 & 1.387 & 1.386 & 1.390 \\
\hline $\mathrm{N} 1-\mathrm{C} 8$ & 1.402 & 1.403 & 1.400 \\
\hline $\mathrm{N} 2-\mathrm{H} 7$ & 1.027 & 1.027 & 1.028 \\
\hline H7-O1 & 1.833 & 1.837 & 1.822 \\
\hline \multicolumn{4}{|c|}{ Angle $\left({ }^{\circ}\right)$} \\
\hline O1-C7-N1 & 122.3 & 122.4 & 121.8 \\
\hline N1-C8-S1 & 118.5 & 118.4 & 118.5 \\
\hline N2-C8-S1 & 127.1 & 127.2 & 127.0 \\
\hline C8-N2-C9 & 130.0 & 130.0 & 130.0 \\
\hline
\end{tabular}


Further insight into the structures of the product molecules was obtained from ${ }^{1} \mathrm{H}$ NMR spectroscopy. The ${ }^{1} \mathrm{H}$ NMR of BBT-4Cl ligand shows the proton signal belonging to aromatic rings at 7.34-8.16 ppm. The N-H signals appeared at the $12.35 \mathrm{ppm}$ and $14.17 \mathrm{ppm}$ which indicates the presence of $\mathrm{N}-\mathrm{H}$ benzamine $[(\mathrm{N}-\mathrm{H}) 1]$ and the $\mathrm{N}-\mathrm{H}$ thioamide [(N-H)2] moieties, respectively. Similarly, the $\mathrm{BBT}-4 \mathrm{OCH}_{3}$ shows the signal of the corresponding benzothiazole and benzoylthiourea protons at 7.08-8.06. Whereas, the corresponding benzamide and thioamide proton resonances were detected at 12.14 and 14.43 ppm. The chemical shifts for all protons are collected in Table 3. The $(\mathrm{N}-\mathrm{H}) 2$ chemical shift of BBT- $4 \mathrm{OCH}_{3}$ was further downshifted compared to BBT and BBT-4Cl. This observation is influenced by the presence of greater hydrogen bonding effect (Arslan et al. 2006; Kurt et al. 2009; Zhou et al. 2005).

TABLE 3. Chemical shift for BBT, BBT-4Cl and BBT- $4 \mathrm{OCH}_{3}$

\begin{tabular}{cccc}
\hline Compound & $\delta_{(\mathrm{N}-\mathrm{H}) 1}$ & $\delta_{(\mathrm{N}-\mathrm{H}) 2}$ & $\delta_{\mathrm{H} \text { (benzene ring) }}$ \\
\hline BBT & 12.30 & 14.29 & $7.38-8.07$ \\
$\mathrm{BBT}-4 C l$ & 12.35 & 14.17 & $7.34-8.16$ \\
$\mathrm{BBT}^{-4 O C \mathrm{OH}_{3}}$ & 12.14 & 14.43 & $7.08-8.06$ \\
\hline
\end{tabular}

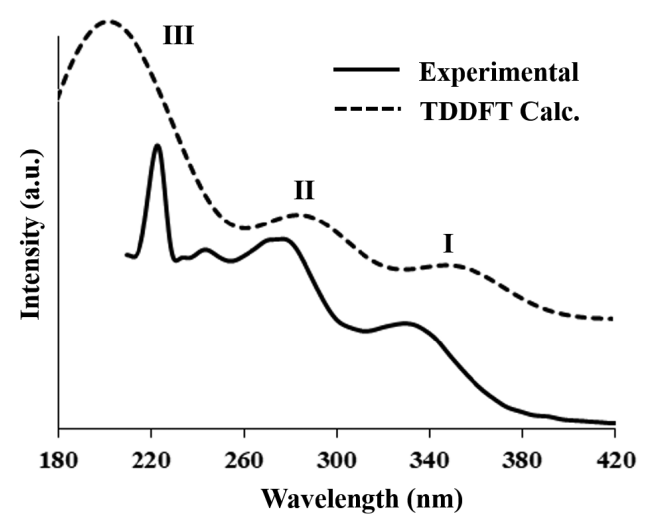

(A)

\section{UV-VIS ABSORPTION STUDY}

The experimental UV-Vis spectrum of BBT showed three prominent absorption bands labelled as I, II and III. A shoulder peak was also observed in the region, 230-250 $\mathrm{nm}$. The TDDFT simulation of the electronic excitation bands has demonstrated a similar spectral profile. The TDDFT simulated band III is relatively broad compared to the experimental one, as a result, the apparent shoulder peak may not be observed due to overlapping absorption bands. A total of one hundred vertical excitation states were considered for the TDDFT calculation. The data obtained was subsequently interpolated with a Gaussiantype distribution curve in Figure 3(A). The UV-Vis absorption information i.e. maxima wavelength $\left(\lambda_{\max }\right)$, optical bandgap $\left(E_{\mathrm{g}}\right)$, extinction coefficient $(\varepsilon)$, oscillator strengths $(f)$, predominant transitions and orbitals involved are shown in Table 4.

Figure 4 illustrates the frontier molecular orbitals, HOMO and LUMO of the three titled compounds. The UV-Vis spectral description will focus on BBT since all three compounds have similar UV-Vis spectral profile in terms of the number of absorption bands. The most intense absorption peak with the highest extinction coefficient belongs to band III ( $\lambda_{\max }=223 \mathrm{~nm}, \varepsilon=3.064$

FIGURE 3. (A) Experimental (solid line) and DFT simulated (dashed line) UV-Vis spectra of BBT in acetonitrile with three dominant absorption bands: I, II and III. (B) Comparison of the first two absorption bands obtained

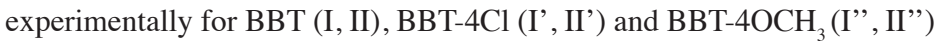

TABLE 4. UV-Vis absorption data measured experimentally and theoretically in acetonitrile for BBT

\begin{tabular}{|c|c|c|c|c|c|c|c|}
\hline \multirow[t]{2}{*}{ Band } & \multicolumn{4}{|c|}{ Expt. } & \multicolumn{3}{|c|}{ TDDFT/B3LYP } \\
\hline & $\begin{array}{l}\lambda_{\max }{ }^{a} \\
(\mathrm{~nm})\end{array}$ & $\begin{array}{c}E_{\mathrm{g}}^{\mathrm{a}} \\
(\mathrm{eV})\end{array}$ & $\varepsilon^{\mathrm{a}}$ & $\begin{array}{l}\lambda_{\max }{ }^{a} \\
(\mathrm{~nm})\end{array}$ & $\begin{array}{c}E_{\mathrm{g}}^{\mathrm{a}} \\
(\mathrm{eV})\end{array}$ & $\begin{array}{l}\text { Osc. }{ }^{\mathrm{a}} \\
(f)\end{array}$ & Key transitions and character ${ }^{\mathrm{b}}$ \\
\hline I & 329 & 3.77 & 1.137 & 353 & 3.51 & 0.3470 & $(98 \%) \mathrm{HOMO}_{(\mathrm{btz})} \rightarrow \mathrm{LUMO}_{(\mathrm{btu})}$ \\
\hline II & 277 & 4.47 & 2.049 & 291 & 4.26 & 0.4758 & $(91 \%) \mathrm{HOMO}_{(*)} \rightarrow \mathrm{LUMO}_{(\mathrm{btu})}$ \\
\hline III & 223 & 5.56 & 3.064 & 217 & 5.74 & 0.4446 & $(24 \%) \mathrm{HOMO}_{(n)} \rightarrow \mathrm{LUMO}+5_{(\mathrm{btz})}$ \\
\hline
\end{tabular}


$\times 10^{4} \mathrm{M}^{-1} \mathrm{~cm}^{-1}$; Calc: $\left.217 \mathrm{~nm}, f=0.4446\right)$. Based on TDDFT calculations, band III is assigned to the, $n \rightarrow \pi^{*}$ electronic transition where the free non-bonding electron pairs $(n)$ of electron rich atoms i.e. $\mathrm{S}, \mathrm{N}$ and $\mathrm{O}$ of the molecule populates the empty molecular orbitals found on the benzothiazole fragment. Moving towards the longer wavelengths, band II involves the photoexcitation of electrons from the lower occupied molecular orbital (HOMO-3) to LUMO. The HOMO-3 is located throughout the molecule which involves the filled $-\pi$ molecular orbitals in the $z$-plane. While the LUMO is predominantly located at the benzoylthiourea moiety involving the empty $\pi^{*}$ orbital in the same direction. The calculated probability of involvement for HOMO- $3 \rightarrow$ LUMO was $91 \%$ since their molecular orbitals are congruent in terms of orientation. The electron excitation recorded at $\lambda_{\max }=$ $329 \mathrm{~nm}, E_{\mathrm{g}}=3.77$ is ascribed to band I. This electronic absorption is identified as the HOMO $\rightarrow$ LUMO transition (98\% probability). The HOMO is mainly found on the benzothiazolyl fragment and the photoexcited electrons move to the opposite end of the molecule towards the benzoylthiourea fragment where the LUMO, empty $\pi^{*}$ molecular orbitals are located.

Among the three compounds, two of which are substituted with either an electron-donating $\left(\mathrm{OCH}_{3}\right)$ or withdrawing $(\mathrm{Cl})$ group, situated at the para position of the benzoyl moiety. Concurrently, the substituent is also located where the mass accumulation of empty molecular orbitals, LUMO is found. Therefore, we would expect that the substituent would affect the LUMO energy level and shift the optical bandgap. The LUMO is basically involved in electronic transitions for the band I and
II (Table 4) and these absorption bands are illustrated in Figure 4(B) for BBT, BBT-4Cl and BBT-4OCH . It $^{2}$ is observed that band I, I' and I" have no significant changes in terms of band position despite the presence of substituents on the benzene ring of a benzoylthiourea fragment. Nevertheless, the position of band II is drastically affected with increasing bathochromic shift in the following order: II < II' < II'. In the unsubstituted compound, BBT, band II involves HOMO-3 where the filled- $\pi$ molecular orbitals are distributed across the entire molecule with a slightly higher participation from the $\mathrm{S}$ atom of thioamide linkage. In comparison with band II, a band I encompass the filled- $\pi$ molecular orbitals of benzothiazole moiety (HOMO), which are situated away from the benzoyl moiety (benzoylthiourea) with parasubstituents $\left(\mathrm{Cl}\right.$ and $\left.\mathrm{OCH}_{3}\right)$. Therefore, the electron withdrawing and donating substituent of $\mathrm{Cl}$ and $\mathrm{OCH}_{3}$, respectively, have a greater influence on the HOMO- 3 . As such, the electron-donating resonance effect induced by the methoxy group outweighed the inductive effect caused by the electron-withdrawing chlorine atom. The ease of electron delocalization within the $\mathrm{BBT}-4 \mathrm{OCH}_{3}$ molecule has lowered the required energy for electronic photo-excitation of band II and hence, a blue-shift was observed. As per discussion, the reduction of optical bandgap which involves the lowest energy electronic absorption band (I) can essentially be achieved with the utilization of electron donors at the benzothiazole moiety, while, the benzoylthiourea moiety should be infused with electron acceptors. Hence, electrons will have a higher affinity to delocalized from the HOMO (benzothiazole) to the LUMO (benzoylthiourea).



(C)

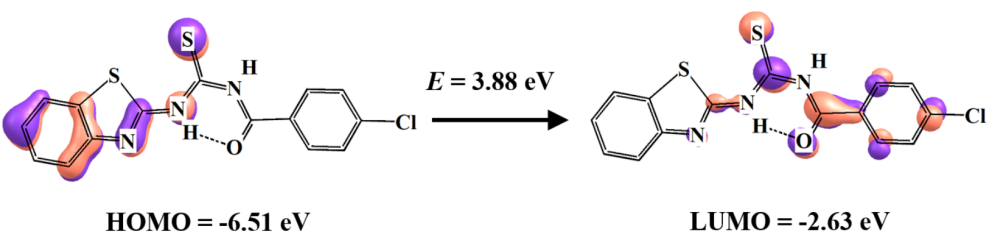

FIGURE 4. Isosurface illustration (contour value $=0.052$ ) of HOMO and LUMO of (A) BBT-4OCH ,

(B) BBT and (C) BBT-4Cl with their ground state energy bandgaps 


\section{CONCLUSION}

Three new compounds namely 1-(1,3-benzothiazol-2-yl)3-(benzoylthiourea) (BBT), 1-(1,3-benzothiazol-2-yl)-3-(4chlorobenzoylthiourea) (BBT-4Cl) and 1-(1,3-benzothiazol2-yl)-3-(4-methoxybenzoylthiourea) $\left(\mathrm{BBT}-4 \mathrm{OCH}_{3}\right)$ were successfully synthesized and showed the presence of intramolecular hydrogen bonding interaction which enhanced the overall geometrical stability in the observed structural conformation. The $\mathrm{Cl}$ and $\mathrm{OCH}_{3}$ substituents influenced the electron density of the benzene ring. The electron delocalization within the molecule was improved via the resonance effect of $\mathrm{OCH}_{3}$ and hence, greatly strengthen the hydrogen bonding. On the contrary, the $\mathrm{Cl}$ substituent weakened the hydrogen bonding by inductively attracting the electron density away from the hydrogen bond. Essentially, the presence of intramolecular hydrogen bond induced structural planarity of the molecule. Tuning of the optical properties can be systematically accessed via the HOMO (benzothiazole) and LUMO (benzoylthiourea) by incorporating proper substituent groups.

\section{ACKNOWLEDGEMENTS}

The authors would like to thank Ministry of Higher Education (MOHE), Malaysia and Universiti Kebangsaan Malaysia (UKM) for the research grant FRGS/1/2012/TK02/ UKM/02/8 and DIP-2016-026. Many thanks to Prof. Hideaki Kasai, Prof. Wilson Agerico Diño and Osaka University (Japan) for supporting us with quantum computational facilities. We are grateful to the School of Chemical Sciences and Food Technology, Faculty of Science and Technology and Fuel Cell Institute (UKM) for their support and provision of experimental facilities.

\section{REFERENCES}

Alkherraz, A.M., Lusta, Z.I. \& Zubi, A.E. 2014. Synthesis and use of thiourea derivative (1-phenyl-3-benzoyl-2-thiourea) for extraction of cadmium ion. International Journal of Chemical, Nuclear, Materials and Metallurgical Engineering 8(2): 116-118.

Al-abbasi, A.A. \& Kassim, M.B. 2011. 1-Benzoyl-3-ethyl-3phenylthiourea Acta Crystallographica Section E: Structure Reports Online 67(3): 611.

Arslan, H., Kulcu, N. \& Florke, U. 2006. Normal coordinate analysis and crystal structure of N, N-dimethyl-N'-(2chlorobenzoyl)thiourea. Spectrochimica Acta Part A 64: 1065-1071.

Becke, A.D. 1993. Density functional thermochemistry III the role of exact exchange. J. Chem. Phys. 98: 5648-5652.

Becke, A.D. 1988. Density-functional exchange-energy approximation with correct asymptotic behaviour. Physical Review A 38(6): 3098-3100.

Cossi, M., Rega, N., Scalmani, G. \& Barone, V. 2003. Molecules in solution with the C-PCM solvation model. Journal of Computational Chemistry 24(6): 669-681.

Đaković, M., Čičak, H., Soldin, Ž. \& Tralić-Kulenović, V. 2009. Structural and computational studies of geometric isomers of 2-(4-methoxystyryl)-1,3-benzothiazole and preparation of their complexes with zinc halides. Journal of Molecular Structure 938: 125-132.

Das, D.K. 1984. N- $\alpha$-(5-bromopyridyl)-N'-benzoyl thiourea (BrPBT) as a new chelating agent for the spectrophotometric determination of rhodium (III). Fres. J. Anal. Chem. 318(8): 612 .

Davidson, E.R. \& Feller, D. 1986. Basis set selection for molecular calculations. Chemical Reviews 86(4): 681-696.

Domìnguez,M.,Anticó,E., Beyer,L., Aguirre,A., García-Granda, S. \& Salvadó, V. 2002. Liquid-liquid extraction of palladium (III) and gold (III) with N-benzoyl-N',N'-diethylthiourea and the synthesis of a palladium benzoylthiourea complex. Polyhedron 21: 1429-1437.

Fui, M.L.W., Hang, N.K., Arifin, K., Minggu, L.J. \& Kassim, M.B. 2016. Photocatalytic degradation of bromothymol blue with Ruthenium(II) bipyridyl complex in aqueous basic solution. AIP Conference Proceedings 1784(II): 1-6.

Fui, M.L.W., Hang, N.K., Minggu, L.J., Umar, A.A. \& Kassim, M.B. 2012. Penentuan aras jalur tenaga kompleks tungsten nitrosilditiolena. Sains Malaysiana 41(4): 439-444.

Gao, E.J., Wang, K.H., Gu, X.F., Yu, Y., Sun, Y.G., Zhang, W.Z., Yin, H.X., Wu, Q., Zhu, M.C. \& Yan, X.M. 2007. A novel binuclear palladium complex with benzothiazole-2-thiolate: Synthesis, crystal structure, and interaction with DNA. Journal of Inorganic Biochemistry 101: 1404-1409.

Hehre, W.J., Radom, L., Schleyer, P.V.R. \& Pople, J.A. 1986. Ab initio molecular orbital theory. Accounts of Chemical Research 9: 399-406.

Katritzky, A.R. \& Gordeev, M.F. 1991. New 1 H-benzotriazolemediated synthesis of $\mathrm{N}, \mathrm{N}$ '-disubstituted thioureas and carboimides. J. Chem. Soc. 1: 2199-2203.

Kurt, G., Sevgi, F. \& Mercimek, B. 2009. Synthesis, characterization, and antimicrobial activity of new benzoylthiourea ligands. Chemical Papers 63(5): 548-553.

Lee, C., Yang, W. \& Parr, R. 1988. Development of the collesalvetti correlation energy formula into a functional of the electron density. Phys. Rev. B 37(2): 785-789.

Li, G., Hu, K., Yi, C., Knappenberger Jr., K.L., Meyer, G.J., Gorelsky, S.I. \& Shatruk, M. 2013. Panchromatic light harvesting and hot electron injection by $\mathrm{Ru}(\mathrm{II})$ dipyrrinates on a $\mathrm{TiO}_{2}$ surface. J. Phys. Chem. 117(34): 17399-17411.

Mark-Lee, W.F., Ng, K.H., Minggu, L.J., Umar, A.A. \& Kassim, M.B. 2013. A molybdenum dithiolene complex as a potential photosensitizer for photoelectrochemical cells. International Journal of Hydrogen Energy 38(22): 9578-9584.

Mark-Lee, W.F., Rusydi, F., Minggu, L.J. \& Kassim, M.B. 2017. Bis(Bipyridyl)-Ru(II)-1-benzoyl-3-(pyridine-2-yl)$1 \mathrm{H}$-pyrazole as potential photosensitiser: Experimental and density functional theory study. Jurnal Teknologi 79(5-3): 117-123.

Miertuš, S., Scrocco, E. \& Tomasi, J. 1981. Electrostatic interaction of a solute with a continuum. A direct utilization of Ab initio molecular potentials for the provision of solvent effects. Chemical Physics 55(1): 117-129.

Mishra, A., Fischer, M.K.R. \& Bauerle, P. 2009. Metal-free organic dyes for dye-sensitized solar cells: From structure: Property relationships to design rules. Angewandte Chemie International Edition 49(14): 2474-2499.

Mohammad Halim, N.I., Kassim, K., Fadzli,A.H. \& Yamin, B.M. 2012. Synthesis, characterization and antibacterial studies of $\mathrm{Cu}(\mathrm{II})$ complexes thiourea. The Malaysian Journal of Analytical Sciences 16(1): 56-61. 
Perez,H., Correa, R.S., Plutin, A.M. \& Mascarenhas, A.Y. 2011 N-Benzoyl-N',N'-dimethylthiourea. Acta Crystallography, Sect.E 67: 0647.

Raj, S.S.S., Puviarasan, K., Velmurugan, D., Jayanthi, G. \& Fun, H.K. 1999. N H S hydrogen bonding in N-benzoyl-N'-methyl$\mathrm{N}$-phenylthiourea and N-benzoyl-N'-(3,4-dimethylphenyl) thiourea. Acta Crystallography C55: 1318-1320.

Saeed, S., Rashid, N., Jones, P.G., Ali, R. \& Hussain, M. 2010. Synthesis, characterization and biological evaluation of some thiourea derivatives bearing benzothiazole moiety as potential antimicrobial and anticancer agents. European Journal of Medicinal Chemistry 45: 1323-1331.

Sathdeo, S., Schoultz, X., Gerber, T.I.A., Betz, R. \& Hosten, E.C. 2016. Reactivity of a benzothiazole-thiourea derivative with the oxorhenium (V) core: Isolation of rhenium (III) and (V) complexes. Polyhedron. 112: 1-5.

Sayama, K., Tsukagoshi, S., Hara, K., Ohga, Y., Shinpou, A., Abe, Y., Suga, S.\& Arakawa, H. 2002. Photoelectrochemical properties of $\mathrm{J}$ aggregates of benzothiazole merocyanine dyes on a nanostructured $\mathrm{TiO}_{2}$ film. The Journal of Physical Chemistry B 106(6): 1363-1371.

Schoultz, X., Gerber, T.I.A. \& Hosten, E.C. 2016. Rhenium (I) complexes with benzothiazole-thiourea derivatives. Polyhedron 113: 55-60.

Selvarakumaran, N., Pratheepkumar, A., Ng, S.W., Tiekink, E.R.T. \& Karvembu, R. 2011. Versatile coordination behaviour of N, N-di(alkyl/aryl)-N'-benzoylthiourea ligands: Synthesis, crystal structure and cytotoxicity of palladium (II) complexes. Inorganica Chimica Acta 376: 278-284.

Shome, S.C., Mazumdar, M. \& Haldar, P.K. 1980. N-AlphaPyridyl-N'-Benzoyl thiourea as a chelating agent for the determination of iridium. J. Chem. 57(2): 139-141.

Tan, S.S., Al-abbasi, A.A., Tahir, M.I.M. \& Kassim, M.B. 2014. Synthesis, structure and spectroscopic properties of cobalt(III) complexes with 1-(benzoyl-(3,3-disubstituted) thiourea. Polyhedron 68: 287-294.

Thompson, L.K., Ball, R.G. \& Trotter, J. 1980. Complexes of substituted benzothiazoles. 2. Copper (II) complexes of the 'tripod' ligand tris(2-benzothiazoylmethyl)amine. Can. J. Chem. 58: 1566.
Weiqun, Z., Kuisheng, L., Yong, Z.\& Lu, L. 2003. Structural and spectral studies of N-(4-chloro)benzoyl-N'-2-tolylthiourea. Journal of Molecular Structure 657: 215-223.

Yang, W., Liu, H., Li, M., Wang, F., Zhou, W. \& Fan, J. 2012. Synthesis, structures and antibacterial activities of benzoylthiourea derivatives and their complexes with cobalt. Journal of Inorganic Biochemistry 116: 97-105.

Yusof, M.S., Jusoh, R.H., Khairul, W.M. \& Yamin, B.M. 2010. Synthesis and characterization a series of $\mathrm{N}-(3,4-$ dichlorophenyl)-N'-(2,3 and 4-methylbenzoyl)thiourea derivatives. Journal of Molecular Structure 975: 280-284.

Yutronic, N., Manriquez, V., Jara, P., Witke, O., Merchan, J. \& Gonzalez, G. 2000. Bis(thiourea)-1,4-diazabicyclo[2.2.2] octane. A new layered thiourea inclusion compound. Journal of the Chemical Society, Perkin Transactions 2 8: 1757.

Zhou, W.Q., Li, B.L., Cao, Y., Zhang, Y., Lu, L.D. \& Yang, X.J. 2005. The structure and conformation analysis of N-2fluorobenzoyl-N'-2-methoxy phenyl thiourea. Journal of Molecular Structure: Theochem 730: 131-139.

Muhd Hafizi B.Zainal, Wun Fui Mark-Lee, Syahidah Mohd Tahir, Ishak B. Ahmad \& Mohammad B. Kassim*

School of Chemical and Food Technology

Faculty of Science and Technology

Universiti Kebangsaan Malaysia

43600 UKM Bangi, Selangor Darul Ehsan

Malaysia

Mohammad B. Kassim*

Fuel Cell Institute

Universiti Kebangsaan Malaysia

43600 UKM Bangi, Selangor Darul Ehsan

Malaysia

*Corresponding author; email: mb_kassim@ukm.edu.my

Received: 20 September 2017

Accepted: 29 December 2017 